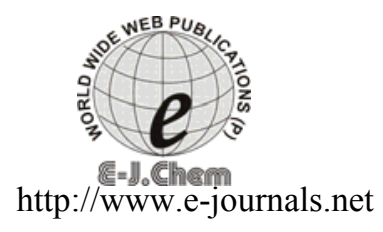

\title{
Synthesis and Structural Characterization of 'Non-VSEPR' Structures of Oxo-Tungsten Complex
}

\author{
SHAHRIARE GHAMMAMY ${ }^{{ }^{*}}$ and HAJAR SAHEBALZAMANI ${ }^{\S}$ \\ *Department of Chemistry \\ Islamic Azad University, Malard Branch, Tehran, Iran \\ ${ }^{\S}$ Departments of Chemistry, Faculty of Science \\ Islamic Azad University, Ardabil Branch, Ardabil, Iran \\ shghamami@yahoo.com
}

Received 18 December 2010; Accepted 28 February 2011

\begin{abstract}
The crystal structure of $\left[\left(\mathrm{CH}_{3}\right)_{4} \mathrm{~N}\right]_{4}\left[\mathrm{WOCl}_{4} \mathrm{~F}\right]\left[\mathrm{WO}_{2} \mathrm{Cl}_{4}\right]$ was determined by single crystal $\mathrm{X}$-ray diffraction technique. The crystal is monoclinic, space group $\mathrm{C} 2 / \mathrm{m}$, with $\mathrm{a}=28.23(10) \AA, \mathrm{b}=11.60(4) \AA, \mathrm{c}=$ 13.48(5) $\AA, \beta=118.43(7)^{\circ}, V=3886(2) \AA^{3}, Z=4$. The structure was solved by direct methods and refined by least-squares methods to a final $\mathrm{R}=$ 0.0512 for 3825 observed reflections with $\mathrm{I}>2 \sigma(\mathrm{I})$. In crystal there are two crystallographic distinct anions, both with cis geometry; the O-W-F and O$\mathrm{W}-\mathrm{O}$ angles are $97.5(3)^{\circ}$ and $103.1(3)^{\circ}$ respectively. All structures are cis configurations that confirm a preference for angles below $90^{\circ}$ and $180^{\circ}$ between cis and trans $\sigma$-donor ligands, respectively.
\end{abstract}

Keywords: X-ray crystal structure, Synthesis, IR spectra, Oxo- tungsten

\section{Introduction}

Under certain circumstances, metal complexes with a formal $\mathrm{d}^{0}$ electronic configuration may exhibit structures that violate the traditional structure models, such as the VSEPR concept or simple ionic pictures. Some examples of the behavior, such as the bent gas phase structures of some alkaline earth dihalides or the trigonal prismatic coordination of some early transition metal chalcogenides or pnictides, have been known for a long time. However, the number of molecular examples for 'non-VSEPR' structures has increased dramatically during the past decade, in particular in the realm of organometallic chemistry. At the same time, various theoretical models have been discussed, sometimes controversially, to explain the observed, unusual structures. Many $\mathrm{d}^{0}$ systems are important in homogeneous and heterogeneous catalysis, biocatalysis (e.g. molybdenum or tungsten enzymes). 
The development of improved models for chemical bonding has always benefited from specific cases in which the existing models fail. One well-known example is the failure of the widely used valence-shell electron-pair-repulsion (VSEPR) ${ }^{1}$ model and also of simple ionic models to predict the bent structures of some of the molecular dihalides of the heavy alkaline earth metals $(\mathrm{Ca}, \mathrm{Sr}$ and $\mathrm{Ba})$ in the gas phase $\mathrm{e}^{2-10}$. Many more complexes with a formal $\mathrm{d}^{0}$ configuration of the central metal (and also with $\mathrm{d}^{1}$ and $\mathrm{d}^{2}$ configurations) have since been found, which do not conform to the simple structural models.

The increasing number of known non octahedral hexacoordinate $\mathrm{d}^{0}, \mathrm{~d}^{1}$ and $\mathrm{d}^{2}$ complexes represents probably the most spectacular failure of the traditional structure models in this area of the periodic table. The octahedron, which is clearly favored by ligand repulsion ${ }^{11}$, has been and still is by far the predominant geometry for this coordination number, both in main group and in transition metal chemistry.

Depending on the actual combination of $\sigma$-donor and $\pi$-donor ligands, we may expect a considerable variety of coordination arrangements. Very recently, Seppelt et al ${ }^{12}$ succeeded in carrying out initial solid-state structures determinations for four heteroleptic systems, $\left[\mathrm{MoO}\left(\mathrm{CH}_{3}\right)_{5}\right],\left[\mathrm{WCl}\left(\mathrm{CH}_{3}\right)_{5}\right],\left[\mathrm{Mo}\left(\mathrm{OCH}_{3}\right)_{2}\left(\mathrm{CH}_{3}\right)_{4}\right]$ and $\left[\mathrm{MoCl}\left(\mathrm{OCH}_{3}\right)_{2}\left(\mathrm{CH}_{3}\right)_{3}\right]$. While the first three complexes are close to trigonal-prismatic limit, the latter complex appears to prefer a distorted octahedral arrangement, which resembles strikingly a low-lying transition state computed for $\left[\mathrm{WCl}_{3}\left(\mathrm{CH}_{3}\right)_{3}\right]$. The results of these studies confirm a preference for angles below $90^{\circ}$ and $180^{\circ}$ between cis and trans $\sigma$-donor ligands, respectively. For studying the effect of various kinds of $\pi$-donor and $\mathrm{d}^{0}$ system structures, we report here the synthesis and structures of oxo-tungsten.

\section{Experimental}

IR spectrum of the complex dispersed in $\mathrm{KBr}$ was recorded on a Shimadzu model 420 spectrophotometer. All reaction and air-sensitive product was manipulated in auto recirculating positive dry boxes, that purched by argon. Acetonitrile (Merck, PA) was twice distilled from phosphorus pentaoxide, to remove traces of moisture and stored over molecular sieves (type $4 \AA$ ) activated at $390{ }^{\circ} \mathrm{C}$. The $\left(\mathrm{CH}_{3}\right)_{4} \mathrm{NF} .2 \mathrm{H}_{2} \mathrm{O}$ was prepared from $\left(\mathrm{CH}_{3}\right)_{4} \mathrm{NOH}$ and $\mathrm{HF}$ as described in the literature ${ }^{13}$.

\section{Preparation of $\left[\left(\mathrm{CH}_{3}\right)_{4} \mathrm{~N}_{4}\left[\mathrm{WOCl}_{4} \mathrm{~F}\right]\left[\mathrm{WO}_{2} \mathrm{Cl}_{4}\right] \cdot 2 \mathrm{CH}_{3} \mathrm{CN}\right.$ (1)}

Tungsten oxotetrachloride, WOCl4, is very reactive compound. It reacted with oxygen if exposed to air. Inside a glove box purged by argon, a measured amount of tungsten (VI) oxotetrachloride $(1 \mathrm{~g})$ is dissolved in acetonitrile $(25 \mathrm{~mL})$ in a polyethylene beaker and stoichiometric amount of tetramethylammonium fluoride Dehydrate, $\left(\mathrm{CH}_{3}\right)_{4} \mathrm{NF}, 2 \mathrm{H}_{2} \mathrm{O}$ was added with stirring at room temperature. On refrigerating, solid product formed and gave suitable crystals after one week. Anal.Calcd for $\mathrm{C}_{20} \mathrm{H}_{54} \mathrm{Cl}_{8} \mathrm{FN}_{6} \mathrm{O}_{3} \mathrm{~W}_{2}(\%)$ : C, 21.87; H, 4.92; N, 7.65. Found: C, 21.92; H, 4.89; N, 7.71.

\section{$X$-ray crystallography}

The intensity data for light green prism crystal of complex was measured on a Bruker SMART $1000 \mathrm{CCD}$ area-detector, temperature 153(2) K, Mo Ka radiation $\left(\mathrm{k}=0.71073 \mathrm{~A}^{\circ}\right)$, graphite monochromator, phi and omega scans, Data collection and cell refinement with SMART $^{14}$, data reduction with SAINT ${ }^{15}$, experimental absorption correction with SADABS $^{16}$. Structure analysis and refinement: The structure was solved by direct methods (SHELXS-97) ${ }^{17}$; refinement was done by full-matrix least-squares on $\mathrm{F}^{2}$ using the SHELXL97 program suite ${ }^{17}$. Crystal data and structure refinement are given in Table 1. 
Table 1. Crystal data and structure refinement for the complex

\begin{tabular}{|c|c|}
\hline Empirical formula & $\mathrm{C}_{20} \mathrm{H}_{54} \mathrm{Cl}_{8} \mathrm{FN}_{6} \mathrm{O}_{3} \mathrm{~W}_{2}$ \\
\hline Formula weight & 1096.99 \\
\hline Temperature (K) & $153(2) \mathrm{K}$ \\
\hline Wavelength $(\AA ̊)$ & 0.71073 \\
\hline Crystal system & monoclinic \\
\hline Space group & $\mathrm{C} 2 / \mathrm{m}$ \\
\hline \multicolumn{2}{|l|}{ Unit cell dimensions } \\
\hline $\mathrm{a}(\AA \hat{\prime})$ & $28.233(10)$ \\
\hline $\mathrm{b}(\hat{\prime})$ & $11.606(4)$ \\
\hline $\mathrm{c}(\AA ⿻)$ & $13.487(5)$ \\
\hline$\alpha\left(\AA^{\circ}\right)$ & 90 \\
\hline$\beta\left(^{\circ}\right)$ & $118.437(7)$ \\
\hline$\gamma\left({ }^{\circ}\right)$ & 90 \\
\hline $\mathrm{V}\left(\AA^{3}\right)$ & $3886(2)$ \\
\hline $\mathrm{Z}$ & 4 \\
\hline $\mathrm{D}_{\text {calc, }}, \mathrm{Mg} \mathrm{m}^{-3}$ & 1.875 \\
\hline Absorption coefficient, $\mathrm{mm}^{-1}$ & 6.501 \\
\hline $\mathrm{F}(000)$ & 2132 \\
\hline Crystal size, $\mathrm{mm}$ & $0.25 \times 0.12 \times 0.10$ \\
\hline$\theta$ range for data collection $\left({ }^{\circ}\right)$ & 1.72 to 29.08 \\
\hline Index ranges & $-38<=\mathrm{h}<=38,-15<=\mathrm{k}<=15,-18<=\mathrm{l}<=18$ \\
\hline Reflections collected & 19690 \\
\hline Independent reflections & $5353[\mathrm{R}(\mathrm{int})=0.0345]$ \\
\hline Completeness of theta. $\%$ & $98.0 \%$ \\
\hline Max./min. transmission & 0.785 and 0.467 \\
\hline Refinement method & Full-matrix least-squares on $\mathrm{F}^{2}$ \\
\hline Data / restraints / parameters & $5353 / 0 / 221$ \\
\hline Goodness-of-fit on $\mathrm{F}^{2}$ & 1.122 \\
\hline Final $R$ indices $[\mathrm{I}>2 \sigma(\mathrm{I})]$ & $R 1=0.0512, w R 2=0.1032$ \\
\hline $\mathrm{R}$ indices (all data) & $\mathrm{R} 1=0.0701, \mathrm{wR} 2=0.1098$ \\
\hline
\end{tabular}

\section{Results and Discussion}

\section{IR spectra}

The assignments of IR bands are observed to be in good agreement with the X-ray structural data. The main stretching frequencies of the IR spectrum of the complex are tabulated in Table 2 . The assignments of the IR spectrum in Table 2 refer to the cation and anion respectively. This type of hydrogen bonding in tetramethylammonium salts has been studied and reported by Harmon.

Table 2. The frequencies $\left(\mathrm{cm}^{-1}\right)$ and assignment of cation and anion of compound (1)

\begin{tabular}{|c|c|c|c|c|c|}
\hline$v, \mathrm{~cm}^{-1}$ & Assignment & Intensity & $\mathrm{v}, \mathrm{cm}^{-1}$ & Assignment & Intensity \\
\hline & $\left(\mathrm{CH}_{3}\right)_{4} \mathrm{~N}^{+}$ & & 472 & $v_{19}$ & $\mathrm{~ms}$ \\
\hline 3435 & $v_{\mathrm{CH} 3}+v_{19}$ & $(\mathrm{w}, \mathrm{br})$. & 441 & $v_{19}$ & $\mathrm{~ms}$ \\
\hline 3315 & $v_{\mathrm{CH} 3}+v_{8}$ & (w, br.) & \multicolumn{3}{|c|}{$\left[\mathrm{WCl}_{4} \mathrm{O}_{2}\right]^{-3},\left[\mathrm{WCl}_{4} \mathrm{FO}\right]^{-}$} \\
\hline 3016 & $v_{13}$ & (w, br) & \multirow{3}{*}{$\begin{array}{r}1024 \\
932 \\
568\end{array}$} & \multirow{3}{*}{\multicolumn{2}{|c|}{$\begin{array}{c}v_{\mathrm{s}}(\mathrm{W}=\mathrm{O}) \\
v_{\mathrm{s}}(\mathrm{W}=\mathrm{O}) \\
v(\mathrm{~W}-\mathrm{F})\end{array}$}} \\
\hline 2625 & $\mathrm{v}_{114}$ & (w, br.) & & & \\
\hline $\begin{array}{c}1461 \\
953\end{array}$ & $\begin{array}{l}v_{16} \\
v_{18}\end{array}$ & $\begin{array}{l}\text { (s) } \\
\text { (vs) }\end{array}$ & & & \\
\hline
\end{tabular}


The IR spectrum of this compound is similar to tetramethylammonium perchlorate salt. The IR spectrum shows the existence of hydrogen bonding. The comparison and studies of the IR spectrum are similar to in Harmon's study.

The IR spectrum of the ligand displays bands at 1024, 932 and $568 \mathrm{~cm}^{-1}$, which may be assigned to $v_{\mathrm{s}}(\mathrm{W}=\mathrm{O}), v_{\mathrm{s}}(\mathrm{W}=\mathrm{O}), \mathrm{v}(\mathrm{W}-\mathrm{F}) \mathrm{cm}^{-1}$ for anions respectively. The complex spectrum shows band at around $v\left(\mathrm{CH}_{3}+v_{19}\right)$ at $3435, v\left(v \mathrm{CH}_{3}+v_{8}\right)$ at $3315, v_{13}$ at 3016, $v_{14}$ at $2625, v_{16}$ at $1461, v_{18} 953, v_{19} 472$ and $441 \mathrm{~cm}^{-1}$ for cation. The results are also confirmed by the crystal structure analyses above.

\section{Description of structures}

Tungsten is one of the important transition metals in biological systems ${ }^{18}$. It is an integral component of the multinuclear $\mathrm{M}$ center of nitrogenases and the active sites of a group of oxotransferases $^{19}$. Its unique properties appear to be due to its ability to exist in a number of different oxidation states and to coordinate with a variety of ligands. $\mathrm{W}(\mathrm{V})$ and $\mathrm{W}(\mathrm{VI})$ are generally thought to be the most likely oxidation states involved. Mixed Valence tungsten (V, VI) Compounds have been known several years ago. The mixed valence compounds commonly formed in preparation process ${ }^{20,21}$. As seen crystal structure contains anionic Tungsten ions: a) tetrachlorofluorooxo ion b) tetrachlorodioxo. The coordination geometry about the molybdenum centre in each of these anions is essentially distorted octahedral. The $\mathrm{X}$-ray data clearly demonstrate such inequality (Figures 1 and 2).

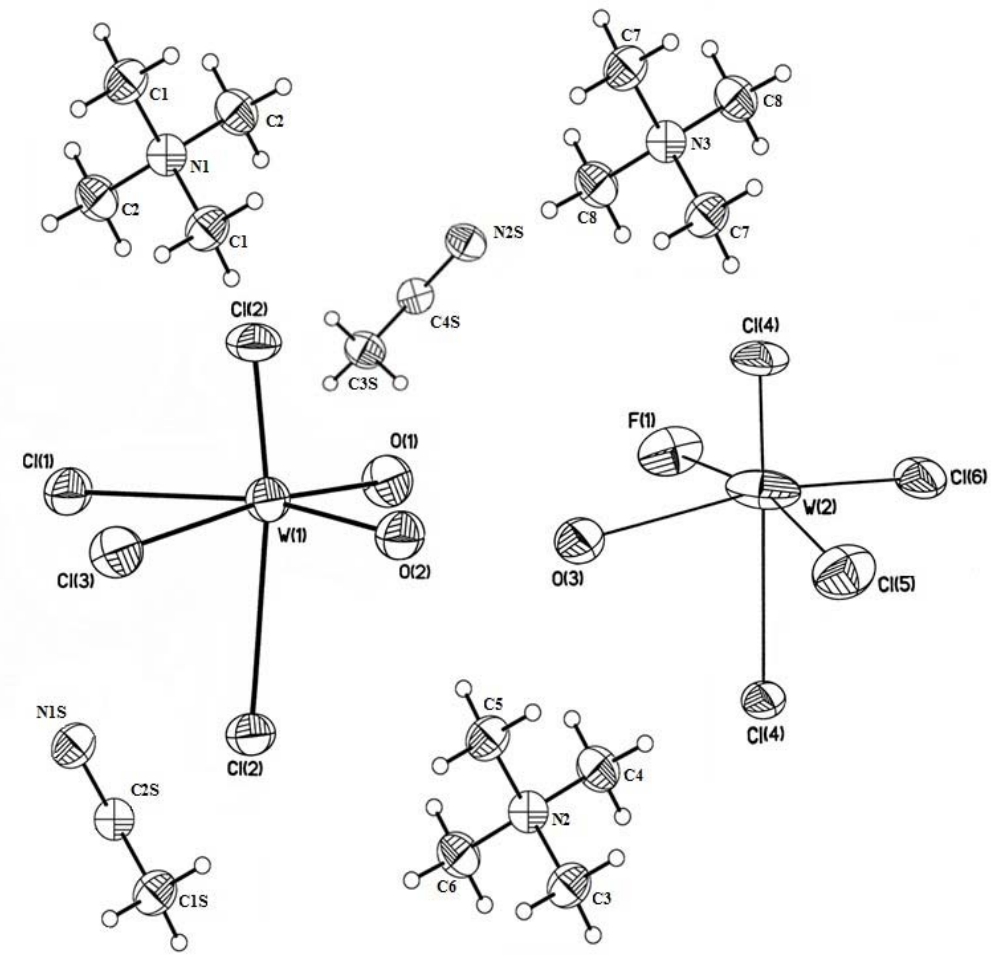

Figure 1. A view of the anionic $\left[\mathrm{WCl}_{4} \mathrm{O}_{2}\right]^{-3},\left[\mathrm{WCl}_{4} \mathrm{FO}\right]^{-}$and three independent $\left[\mathrm{N}\left(\mathrm{CH}_{3}\right)_{4}\right]^{+}$ cations and the acetonitrile solvent molecules. Displacement ellipsoids are shown at the $50 \%$ probability level 


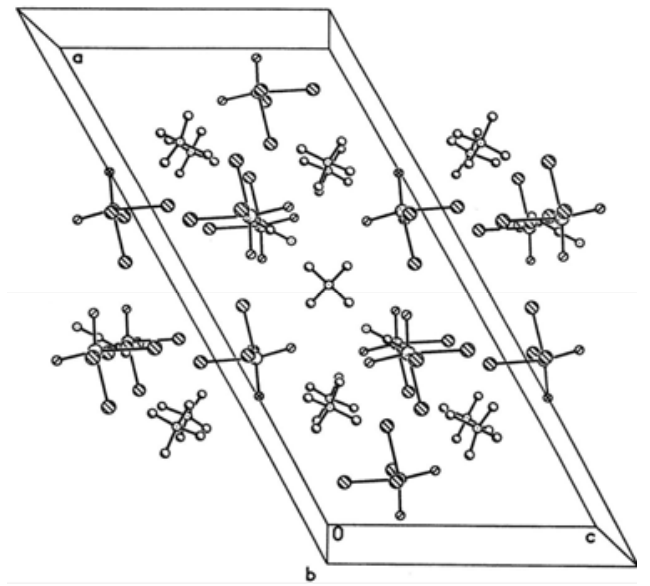

Figure 2. Crystal packing of the $\left[\left(\mathrm{CH}_{3}\right)_{4} \mathrm{~N}\right]_{4}\left[\mathrm{WOCl}_{4} \mathrm{~F}\right]\left[\mathrm{WO}_{2} \mathrm{Cl}_{4}\right], \mathrm{CH}_{3} \mathrm{CN}$

The trans $\mathrm{W}-\mathrm{Cl}$ bonds to the oxygen atom $[\mathrm{W}(1)-\mathrm{Cl}(1)=2.583(2), \mathrm{W}(1)-\mathrm{Cl}(3)=2.564(2)$ and $\mathrm{W}(2)-\mathrm{Cl}(6)=2.563(2)]$ are longer than the cis $\mathrm{W}-\mathrm{Cl}$ distances to oxygen atom $[\mathrm{W}(1)-\mathrm{Cl}(2)$ $=2.3715(18)$ and $\mathrm{W}(2)-\mathrm{Cl}(4)=2.201(3)]$ reflecting the greater trans influence of the oxygen atom as compared to the chlorine atom. The $\mathrm{F}$ atom in $\left[\mathrm{WCl}_{4} \mathrm{FO}\right]$ is oriented cis to the oxo ligands. The W-F bond length $[\mathrm{W}(2)-\mathrm{F}(1)=1.994(6)]$ is shorter than the sum of the single bond radi for $\mathrm{W}$ and the halides. The final atomic coordinates for the non-hydrogen atoms are given in Table 3 and selected bond lengths and angles are resumed in Table 4.

Table 3. Selected bond length $[\AA]$.

\begin{tabular}{cccc}
\hline Bond & Length & Bond & Length \\
\hline $\mathrm{W}(1)-\mathrm{O}(2)$ & $1.961(6)$ & $\mathrm{W}(2)-\mathrm{Cl}(4)$ & $2.201(3)$ \\
$\mathrm{W}(1)-\mathrm{O}(1)$ & $1.719(6)$ & $\mathrm{W}(2)-\mathrm{Cl}(4)$ & $2.465(4)$ \\
$\mathrm{W}(1)-\mathrm{Cl}(2)$ & $2.3715(18)$ & $\mathrm{W}(2)-\mathrm{Cl}(5)$ & $2.482(3)$ \\
$\mathrm{W}(1)-\mathrm{Cl}(3)$ & $2.564(2)$ & $\mathrm{W}(2)-\mathrm{Cl}(6)$ & $2.563(2)$ \\
$\mathrm{W}(1)-\mathrm{Cl}(1)$ & $2.583(2)$ & $\mathrm{W}(2)-\mathrm{O}(3)$ & $1.716(6)$ \\
$\mathrm{W}(2)-\mathrm{F}(1)$ & $1.994(6)$ & & \\
\hline
\end{tabular}

Table 4. selected bond length $[\AA]$.

\begin{tabular}{cccc}
\hline Bond & Angle & Bond & Angle \\
\hline $\mathrm{O}(2)-\mathrm{W}(1)-\mathrm{O}(1)$ & $103.1(3)$ & $\mathrm{O}(3)-\mathrm{W}(2)-\mathrm{F}(1)$ & $97.5(3)$ \\
$\mathrm{O}(2)-\mathrm{W}(1)-\mathrm{Cl}(2)$ & $94.51(4)$ & $\mathrm{O}(3)-\mathrm{W}(2)-\mathrm{Cl}(4)$ & $99.50(11)$ \\
$\mathrm{O}(1)-\mathrm{W}(1)-\mathrm{Cl}(2)$ & $94.24(5)$ & $\mathrm{Cl}(5)-\mathrm{W}(2)-\mathrm{Cl}(6)$ & $84.22(8)$ \\
$\mathrm{O}(2)-\mathrm{W}(1)-\mathrm{Cl}(2)$ & $94.51(4)$ & $\mathrm{F}(1)-\mathrm{W}(2)-\mathrm{Cl}(4)$ & $97.20(10)$ \\
$\mathrm{O}(1)-\mathrm{W}(1)-\mathrm{Cl}(2)$ & $94.24(5)$ & $\mathrm{O}(3)-\mathrm{W}(2)-\mathrm{Cl}(4)$ & $90.12(11)$ \\
$\mathrm{Cl}(2)-\mathrm{W}(1)-\mathrm{Cl}(2)$ & $165.89(8)$ & $\mathrm{F}(1)-\mathrm{W}(2)-\mathrm{Cl}(4)$ & $89.25(10)$ \\
$\mathrm{O}(2)-\mathrm{W}(1)-\mathrm{Cl}(3)$ & $88.2(2)$ & $\mathrm{Cl}(4)-\mathrm{W}(2)-\mathrm{Cl}(4)$ & $167.58(10)$ \\
$\mathrm{O}(1)-\mathrm{W}(1)-\mathrm{Cl}(3)$ & $168.6(2)$ & $\mathrm{O}(3)-\mathrm{W}(2)-\mathrm{Cl}(5)$ & $90.2(3)$ \\
$\mathrm{Cl}(2)-\mathrm{W}(1)-\mathrm{Cl}(3)$ & $84.73(4)$ & $\mathrm{F}(1)-\mathrm{W}(2)-\mathrm{Cl}(5)$ & $169.28(15)$ \\
$\mathrm{O}(2)-\mathrm{W}(1)-\mathrm{Cl}(1)$ & $168.8(2)$ & $\mathrm{Cl}(4)-\mathrm{W}(2)-\mathrm{Cl}(5)$ & $88.87(9)$ \\
$\mathrm{O}(1)-\mathrm{W}(1)-\mathrm{Cl}(1)$ & $88.1(2)$ & $\mathrm{O}(3)-\mathrm{W}(2)-\mathrm{Cl}(6)$ & $170.95(19)$ \\
$\mathrm{Cl}(2)-\mathrm{W}(1)-\mathrm{Cl}(1)$ & $84.52(4)$ & $\mathrm{F}(1)-\mathrm{W}(2)-\mathrm{Cl}(6)$ & $87.22(16)$ \\
$\mathrm{Cl}(2)-\mathrm{W}(1)-\mathrm{Cl}(1)$ & $84.52(4)$ & $\mathrm{Cl}(4)-\mathrm{W}(2)-\mathrm{Cl}(6)$ & $87.52(8)$ \\
\hline
\end{tabular}


However there are also several cases with strong $\pi$-donor ligands, for which $\pi$ bonding has been considered to increase the deviations from the VSEPR-type arrangements. Depending on the actual combination of $\sigma$-donor and single or double-faced $\pi$-donor ligand, we may expected a considerably variety of coordination arrangements ${ }^{22}$.

The results of these studies confirm a preference for angles below $90^{\circ}$ and below $180^{\circ}$ between cis and trans $\delta$-donor ligands, respectively. At the same time, the distortions allow the competing $\pi$-donor ligands to enhance their bonding to the metal. These conclusions are consistent with more general notions about the alleviation, by structural distortions, of conflicts between different $\pi$-donor ligands (or between $\delta$ - and $\pi$-donor ligands) competing for a given set of metal $\mathrm{d}$ orbitals ${ }^{23}$. The prototypical example for this type of competition is that discussed for distorted octahedral dioxotungsten complex, in which the two strong $\pi$-donor oxo ligand prefer a cisoid arrangement and the two weakest co-ligand is located trans to the oxo ligand, with typically small angles between them ${ }^{24}$.

\section{Conclusion}

The $\left[\left(\mathrm{CH}_{3}\right)_{4} \mathrm{~N}\right]_{4}\left[\mathrm{WOCl}_{4} \mathrm{~F}\right]\left[\mathrm{WO}_{2} \mathrm{Cl}_{4}\right] \cdot 2 \mathrm{CH}_{3} \mathrm{CN}$ complex was synthesized, the hydrogen bonds forming between the electronegative atom of anion and methyl hydrogens of the cation. The structure of this compound belongs to the non-VSEPR structures. CCDC, Nos 191520 contains the supplementary crystallographic data for this paper.

\section{References}

1. a) Sidgwick N V, Powell H E, Proc R Soc A, 1940, 175, 153; b) Gillespie R J and Nyholm R S Q, Rev Chem Soc., 1957, 11, 239; c) Gillespie R J, Molecular Geometry, van Nostrand Reinhold, London, 1972; d) Gillespie R J and Hargittai I, The VSEPR Model of Molecular Geometry, Allyn and Bacon, Boston, 1991; e) Gillespie R J and Robinson E A, Angew Chem., 1996, 108, 539-560; f) Gillespie R J and Robinson E A, Angew Chem Int Ed Engl., 1996, 35, 495-514.

2. a) Wharton L, Berg R A and Klemperer W, J Chem Phys., 1963, 39, 2023. b) Büchler A, Stauffer J L, Klemperer W, J Chem Phys., 1964, 40, 3471. c) Büchler A, Stauffer J L, Klemperer W and Wharton L, J Am Chem Soc., 1964, 86, 4544.

3. Kaupp M, Schleyer P von R, Stoll H and Preuss H, J Chem Phys., 1991, 94, 1360.

4. Seijo L, Barandiaran Z and Huzinaga S, J Chem Phys., 1991, 94, 762.

5. Kaupp M, Schleyer P von R, Stoll H and Preuss H, J Am Chem Soc., 1991, 113, 6012.

6. Kaupp M and Schleyer P von R, J Am Chem Soc., 1992, 114, 491.

7. DeKock R L, Peterson M A, Timmer L K, Baerends E J and Vernooijs P, Polyhedron 1990, 9, 1919.

8. Szentpaly L von and Schwerdtfeger P, Chem Phys Lett., 1990, 170, 555.

9. a) Solomonik V G, Ozerova V M, Shiznev V V and Pogrebnaya T B, Russ J Phys Chem., 1985, 59, 217. b) Gole J L, Siu A K Q and Hayes E F, J Chem Phys., 1973, 58, 857. c) Yarkony D R, Hunt W J and Schaefer H F, Mol Phys., 1973, 58, 941. d) Klimenko N M, Musaev D G, Charkin O P, Russ J Inorg Chem., 1984, 29, 639. e) Salzner U and Schleyer P von R, Chem Phys Lett., 1990, 172, 461. f) Hassett D M and Marsden C J, J Chem Soc Chem Commun., 1990, 667. g) Dyke J M and Wright T G, Chem Phys Lett., 1990, 169138.

10. a) Hargittai M, Chem Rev., 2000, 100, 2233. b) Hargittai M, Coord Chem Rev., 1988, 91, 35-88.

11. Hoffmann R, Howell J M and Rossi A R, J Am Chem Soc., 1976, 98, 2484. 
12. a) Brower D C, Templeton J L and Mingos D M P, J Am Chem Soc., 1987, 109, 5203. b) Burdett J K and Albright T A, Inorg Chem., 1979, 18, 2112-2120.

13. Christe K O, Wilson W W, Wilson R D, Bau R and Feng J J, J Am Chem Soc., 1990, 112, 7619.

14. Bruker, SMART, Bruker Molecular Analysis Research Tool, v. 5.059. Bruker AXS, Madison, Wisconsin, USA, 1998 b.

15. Bruker, SAINTPlus Data Reduction and Correction Program v. 6.01, Bruker AXS, Madison, Wisconsin, USA, 1998a.

16. Sheldrick G M, SADABS v.2.01, Bruker/Siemens Area Detector Absorption Correction Program, Bruker AXS, Madison, isconsin, USA, 1998a.

17. Sheldrick G M, SHELXTL v. 5.10, Structure Determination Software Suite, Bruker AXS, Madison, Wisconsin, USA, 1998 b.

18. Hille R, Chem Rev., 1996, 96, 2757-2816.

19. Tran Ba L, Inorg Chem., 2007, 46(13), 5429-5438.

20. DallÏAcqua Lorenzo, Nova Isabella, Lietti Luca, Ramis Guido and Buscac Guido, Giamello Elio, Phys Chem., 2000, 2(21), 4991-4998.

21. Pyykko P and Tamm T, J Phys Chem A, 1997, 101, 8107-8114.

22. Ferguson G, Gildewell C and lavender E S, Acta Crystallogr Sect B, 1999, B 55, 591-600.

23. a) Brower D C, Templeton J L and Mingos D M P, J Am Chem Soc., 1987, 109, 5203.

b) Burdett J K and Albright T A, Inorg Chem., 1979, 18, 2112-2120.

24. a) Pierpont $\mathrm{C}$ G and Downs H H, Inorg Chem., 1977, 16, 2970. b) Butcher R J, Penfold B R and Sinn E, J Chem Soc Dalton Trans., 1979, 668. 


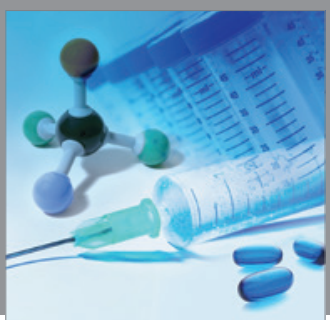

International Journal of

Medicinal Chemistry

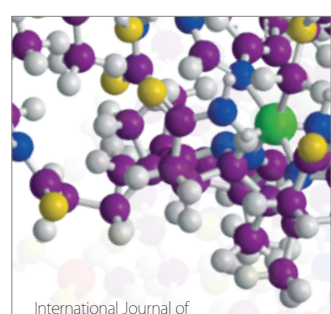

Carbohydrate Chemistry

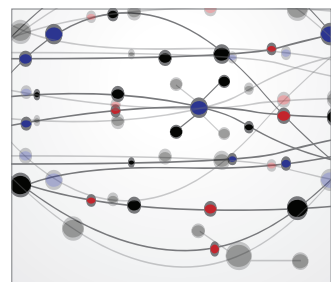

The Scientific World Journal
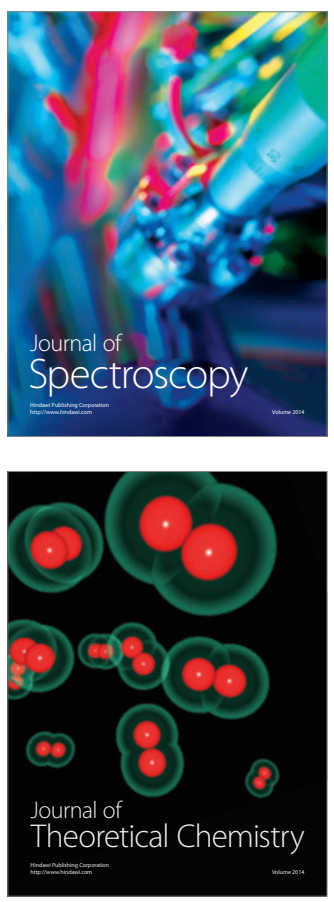
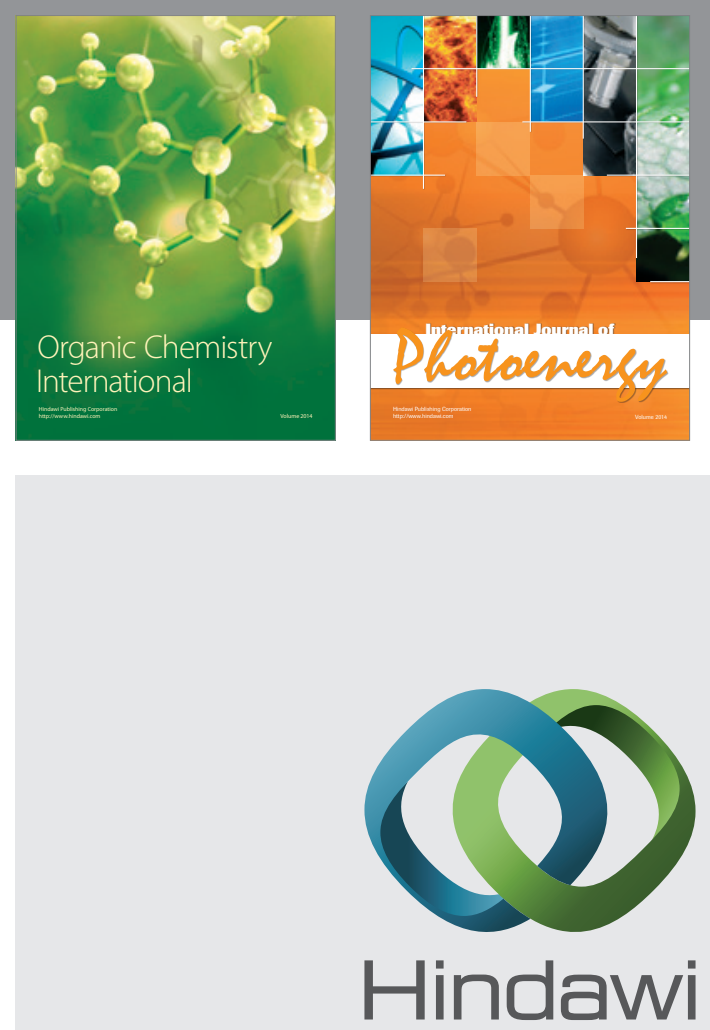

Submit your manuscripts at

http://www.hindawi.com
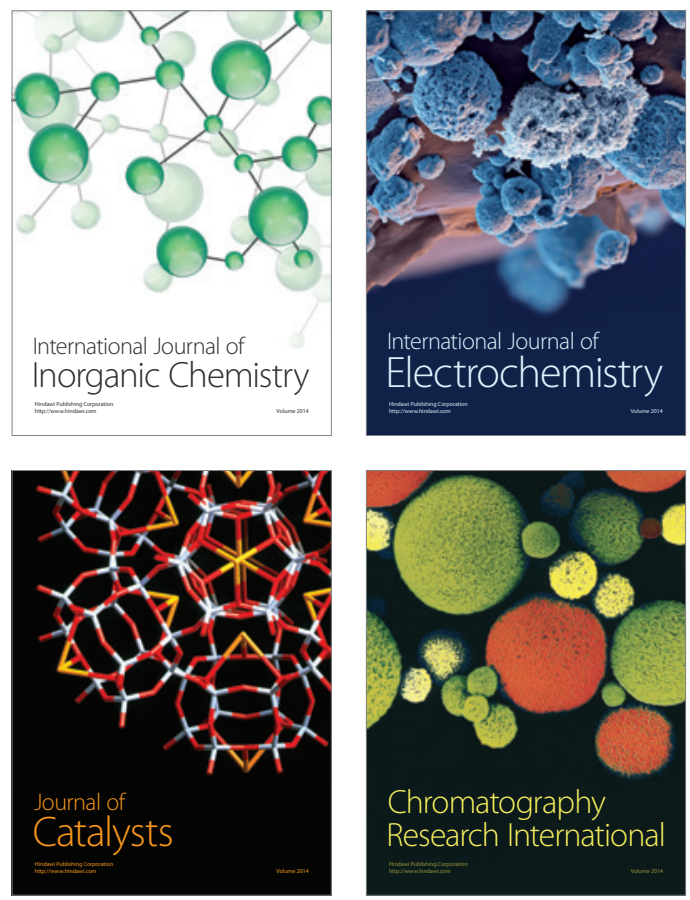
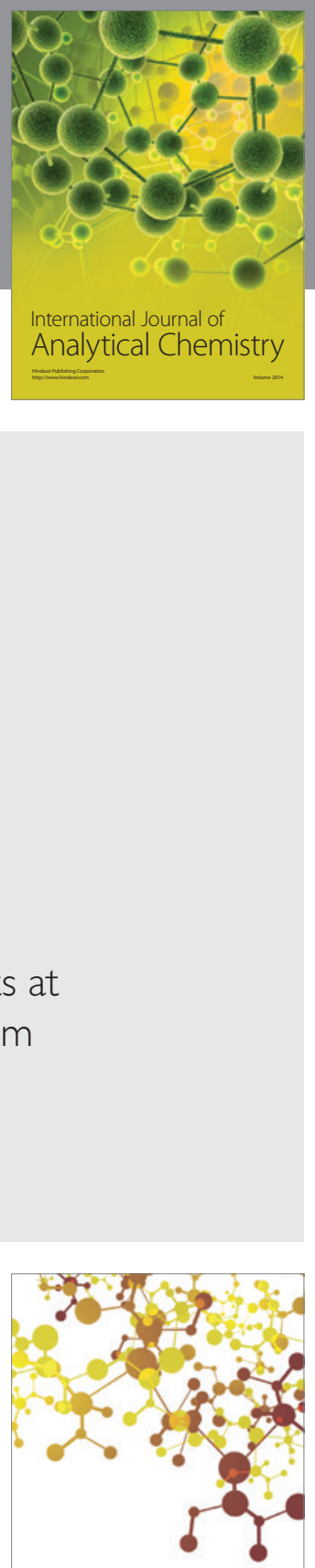

Journal of

Applied Chemistry
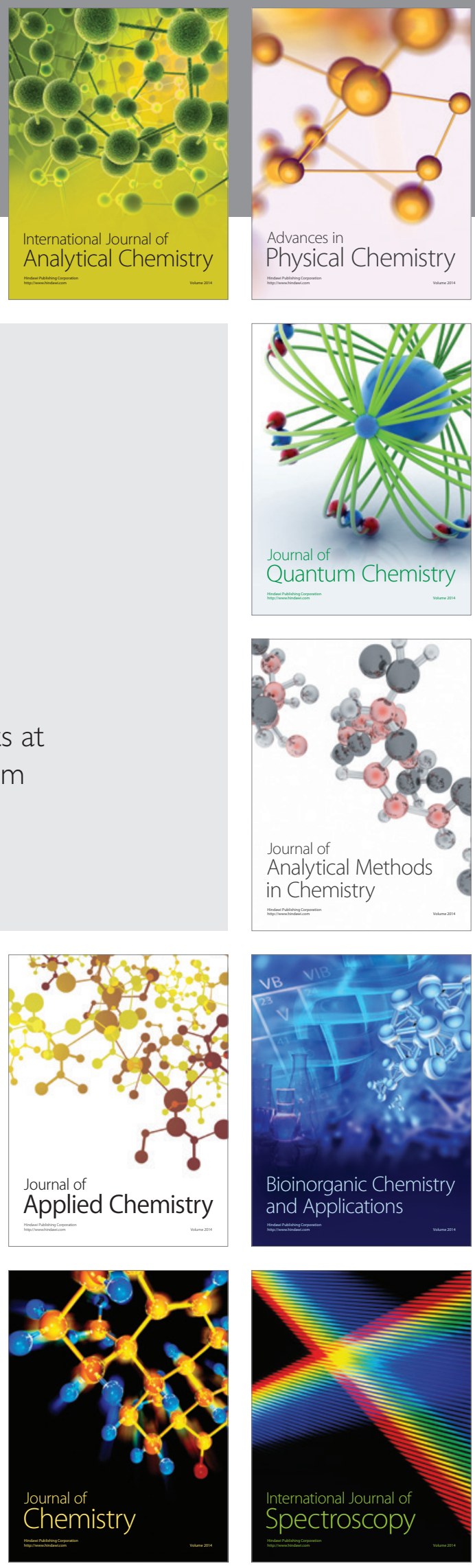